Gut, 1961, 2, 189

\title{
Primary Crohn's disease of the colon and rectum ${ }^{1}$
}

\author{
J. S. CORNES AND METTE STECHER
}

\author{
From the Department of Clinical Pathology, Westminster Medical School, London University, the Gordon \\ Hospital, London, and the Research Department, St. Mark's Hospital, London
}

SYNOPSIS Crohn's disease of the large bowel has been increasingly recognized and this paper presents a clinical and pathological study of 45 patients in whom the disorder was confined entirely to the large intestine. The clinical and pathological factors are contrasted with those of 86 patients with regional ileitis and of 200 patients with ulcerative colitis. Compared with regional ileitis the disease occurred in an older age group, had a different sex distribution, and a higher incidence of perianal and rectovaginal fistulae. A high incidence of recurrent disease following surgical treatment, found in the patients with regional ileitis, was not found in the patients with primary Crohn's disease of the large intestine. The incidence of the disease relative to ulcerative colitis was approximately $6 \%$. The disease had the same sex distribution as ulcerative colitis but occurred in an older age group. The disease was usually of gradual onset and continuous course, and periods of freedom lasting a month or more were uncommon. The patients came to surgery much earlier than patients with ulcerative colitis.

This study began with the examination of a small number of specimens of the large intestine showing many of the pathological features of regional ileitis described by Hadfield (1939), Warren and Sommers (1948): and Rappaport, Burgoyne, and Smetana (1951). The terminal ileum, however, was not involved in any of these cases and the usual preoperative diagnosis was idiopathic ulcerative colitis.

Although the first 13 cases of regional ileitis reported by Crohn, Ginzburg, and Oppenheimer in 1932 affected only the terminal ileum it was soon appreciated that the proximal ileum and jejunum could also be involved (Harris, Bell, and Brunn, 1933), and that the disease might be confined entirely to the jejunum (Brown, Bargen, and Weber, 1934). Involvement of the colon was first reported by Colp in 1934, and later by Donchess and Warren (1934), by Brown et al. (1934), by Crohn and Rosenak (1936), and by others.

Recognition of the disease arising primarily in the large intestine has been retarded by a confusion in nomenclature, by the difficulty in clinical distinction from ulcerative colitis, and by the failure to base published series on adequately studied pathological material. Some pathologists do not distinguish between regional ileitis, regional colitis, and ulcera-

${ }^{1}$ Based on a lecture given in a series of talks on 'Current Pathology' at Westminster Medical School on 27 February 1961. tive colitis, regarding them all as variants of an essentially similar process manifesting itself in different areas of the bowel (Lumb, 1951; Goldgraber, Kirsner, and Palmer, 1959; Lumb and Protheroe, 1958). However, the pathological features of regional ileitis and ulcerative colitis are sufficiently dissimilar for a clear-cut distinction to be made between these two conditions in the vast majority of cases (Rappaport et al., 1951; Warren and Sommers, 1954; Lockhart-Mummery and Morson, 1960).

The confusion in nomenclature has arisen from the use of the words 'regional' or 'segmental' colitis to cover all cases of non-specific chronic inflammation of the large intestine in which the rectum, rectosigmoid, and terminal ileum are not primarily involved (Neuman, Bargen, and Judd, 1954). Defined in this way the term 'regional' colitis embraces at least three different types of disease, namely, ulcerative colitis, secondly a disease with pathological features similar to regional ileitis, and thirdly a disease which fails to show the characteristic pathological features of either regional ileitis or ulcerative colitis. This last type probabiy represents a group of unrecognized disorders.

To overcome the difficulty of nomenclature Harris et al. used the term 'cicatrizing enteritis' to cover all cases with similar clinical and pathological features to the cases of regional ileitis described by Crohn et 
al. Crohn and his colleagues, however, use the term 'granulomatous colitis' to describe cases of regional ileitis with colonic involvement in which the pathological features of the disease in the colon and ileum are identical (Crohn and Yarnis, 1958). Although 'cicatrizing enteritis' and 'granulomatous colitis' are useful terms they do not adequately describe the important and characteristic features of this disease. Cicatrizing enteritis can be found in a number of chronic inflammatory disorders (Lumb, 1951), and granulation tissue may be found in the superficial submucosa in the healing phase of ulcerative colitis (Dukes, 1954). Wells (1952), describing cases of regional colitis characterized by fibrosis, non-caseating tubercles, and multinucleated giant cells, called the condition 'Crohn's disease of the colon'. Because this eponymous title conveys a much fuller meaning than any other term previously employed it has become justly popular with British surgeons and pathologists, and is now an accepted part of our terminology (Dukes and Lockhart-Mummery, 1957; Brooke, 1959; Watkinson, Thompson, and Goligher, 1960; Lockhart-Mummery and Morson, 1960; Nevin, 1961).

Although Crohn's disease of the colon associated with regional ileitis is now a well recognized clinical and pathological entity, very few cases of Crohn's disease arising primarily in the large intestine and in which the small intestine was apparently normal have been reported in the literature. In retrospect some of the cases reported by Moynihan (1907), Robson (1908), Braun (1909), Dalziel (1913), Läwen (1914), Tietze (1920), and Moschcowitz and Wilensky (1923) were probably examples of primary Crohn's disease of the large intestine. Well-documented case reports of this type of disease have been published by James (1938) and by Castleman (1944). Brooke (1959) reported seven cases, in two of which the disease recurred in the small intestine after total proctocolectomy. Lockhart-Mummery and Morson (1960) have recently described 18 cases of primary Crohn's disease of the large intestine and seven cases of regional ileitis with large intestinal involvement.

It is sometimes assumed that primary Crohn's disease of the large intestine occurs in the same type of patient as regional ileitis, and that the clinical behaviour of the disease in the large intestine is similar to that in the small. Goligher (1961) states that there is no reason to suppose Crohn's disease loses its notorious predilection to recurrence because it happens to have transferred its habitat from the small intestine to the large. Dukes (1959), however, believes that a careful distinction should be made between cases of primary Crohn's disease of the large intestine and cases of regional ileitis with or without colonic involvement. This study was under- taken to see if this distinction was worth making, to assess the incidence of primary Crohn's disease of the large intestine relative to ulcerative colitis, and to compare the clinical and pathological features of these cases with cases of regional ileitis and ulcerative colitis.

\section{CASES STUDIED}

This study is based on 45 patients suffering from primary Crohn's disease of the large intestine treated by surgical resection from whom parts or all of the large intestine were available for pathological examination. Only patients in whom the small intestine was shown to be free from disease by radiological examination, inspection at operation, and histological examination of the resected portion of the terminal ileum when it was present in the operation specimen, were included in this group. There was no evidence of active tuberculosis or sarcoidosis, and no acid-fast bacilli could be found in the stools or in sections from lesions in the large intestine and regional lymph nodes. Strict histological criteria were used in the diagnosis of Crohn's disease, and only those patients with a non-specific chronic inflammatory reaction affecting the submucosa, muscle coats and subserosa, associated with fibrosis and the presence of non-caseating nodules of epithelioid histiocytes in the wall of the large intestine or regional lymph nodes, were included.

For comparison a study was made of 86 patients with regional ileitis who had been treated by surgical resection and from whom operation specimens were available for pathological examination.

To assess the incidence of primary Crohn's disease of the large intestine relative to ulcerative colitis a study was made of 200 consecutive patients with proved ulcerative colitis treated by colectomy at the Gordon Hospital, London, and the number of patients with primary Crohn's disease of the large intestine treated by surgical resection at the same hospital over the same period of time was determined. Only those patients with the characteristic pathological features of ulcerative colitis described by Dukes (1954) and by Warren and Sommers (1954) were included in this group.

The clinical records of all the patients included in this study were analyzed, and follow-up studies were made wherever possible.

\section{RESULTS}

AGE AND SEX INCIDENCE The age and sex incidence of the patients in this study are shown in Table $I$. (The age given is the age at onset of symptoms.) Whilst regional ileitis occurred more commonly in 
TABLE I

AGE AND SEX DISTRIBUTION

\begin{tabular}{|c|c|c|c|c|c|c|c|c|c|}
\hline \multirow[t]{2}{*}{$\begin{array}{l}\text { Age } \\
\text { (years) }\end{array}$} & \multicolumn{3}{|c|}{ Regional Ileitis } & \multicolumn{3}{|c|}{ Ulcerative Colitis } & \multicolumn{3}{|c|}{$\begin{array}{l}\text { Primary Crohn's Disease } \\
\text { of Large Intestine }\end{array}$} \\
\hline & Males & Females & Total & Males & Females & Total & Males & Females & Total \\
\hline $0-10$ & 2 & 2 & 4 & 4 & 3 & 7 & 0 & 1 & 1 \\
\hline $11-20$ & 19 & 10 & 29 & 8 & 18 & 26 & 4 & 5 & 9 \\
\hline $21-30$ & 17 & 14 & 31 & 29 & 42 & 71 & 3 & 2 & 5 \\
\hline $31-40$ & 9 & 2 & 11 & 20 & 23 & 43 & 5 & 0 & 5 \\
\hline $41-50$ & 5 & 5 & 10 & 17 & 20 & 37 & 1 & 4 & 5 \\
\hline $51-60$ & 1 & 0 & 1 & 2 & 8 & 10 & 3 & 2 & 5 \\
\hline $61-70$ & 0 & 0 & 0 & 4 & 2 & 6 & 2 & 9 & 11 \\
\hline $71-80$ & 0 & 0 & 0 & 0 & 0 & 0 & 0 & 4 & 4 \\
\hline Total & 53 & 33 & 86 & 84 & 116 & 200 & 18 & 27 & 45 \\
\hline
\end{tabular}

males than in females, ulcerative colitis and primary Crohn's disease of the large intestine occurred more commonly in females than in males. Primary Crohn's disease of the large intestine was found in an older age group than either regional ileitis or ulcerative colitis.

FAMILIAL INCIDENCE Nine patients with ulcerative colitis gave a history of the disease occurring in other members of their families. One woman with regional ileitis had a brother suffering from the same disease. One man with primary Crohn's disease of the large intestine had a brother suffering from regional ileitis.

SYMPTOMS Although diarrhoea, melaena, abdominal pain, weight loss, and fatigue are symptoms common to ulcerative colitis, primary Crohn's disease of the large intestine, and regional ileitis with colonic involvement, a detailed analysis of the data obtained in this study draws attention to certain differences in their symptoms.

Patients with primary Crohn's disease of the large intestine were treated by surgical resection earlier than patients with ulcerative colitis. The number of patients with this disorder undergoing surgical resection within five years of the onset of the disease was $77.8 \%$ compared with $48 \%$ in ulcerative colitis, and after 10 years was $8.9 \%$ compared with $26.5 \%$ in ulcerative colitis.

An acute onset was found more commonly in patients with ulcerative colitis $(29.5 \%)$ than in patients with primary Crohn's disease of the large intestine $(11 \cdot 1 \%)$. Periods of freedom from disease lasting a month or more, which were found in more than half the patients with regional ileitis and ulcerative colitis, were found in only six of the 45 patients with primary Crohn's disease of the large intestine.

All the patients with ulcerative colitis suffered from diarrhoea, although at the onset several of these patients complained of constipation. Diarrhoea occurring in patients with regional ileitis or primary Crohn's disease of the large intestine was usually less severe than that occurring in the patients with ulcerative colitis. Eighteen patients with regional ileitis and four patients with primary Crohn's disease of the large intestine had no diarrhoea.

Despite the frequent finding of occult blood in the stools five patients with ulcerative colitis $(2.5 \%)$, eight patients with primary Crohn's disease of the large intestine $(17 \cdot 8 \%)$, and 49 patients with regional ileitis $(56.9 \%)$ had not noticed any blood in their stools.

EXAMINATION AND INVESTIGATIONS A striking difference was found in the incidence of perianal and rectovaginal fistulae in the three types of disease. These fistulae were found in nearly two-thirds of the patients with primary Crohn's disease of the large intestine, and nearly one-third of the patients with regional ileitis. Compared with ulcerative colitis the characteristic features of the fistulae in regional ileitis and primary Crohn's disease of the large intestine were their indolent appearance, their multiplicity, and their frequency of recurrence after surgical treatment.

A pathological examination was made of the tissues removed from just over half the operations on these fistulae. Although multinucleated foreign body type giant cells were frequently seen in this material, non-caseating tubercles with Langhans type giant cells were found only in material from patients with regional ileitis or primary Crohn's disease of the large intestine.

At sigmoidoscopy the rectal mucosa appeared abnormal in 198 of the 200 patients with ulcerative colitis, in 31 of the 45 patients with primary Crohn's disease of the large intestine, and in 24 of the 86 patients with regional ileitis. Non-caseating tubercles with giant cells were found in the rectal biopsies from a fifth of the patients with rectal disease due to 


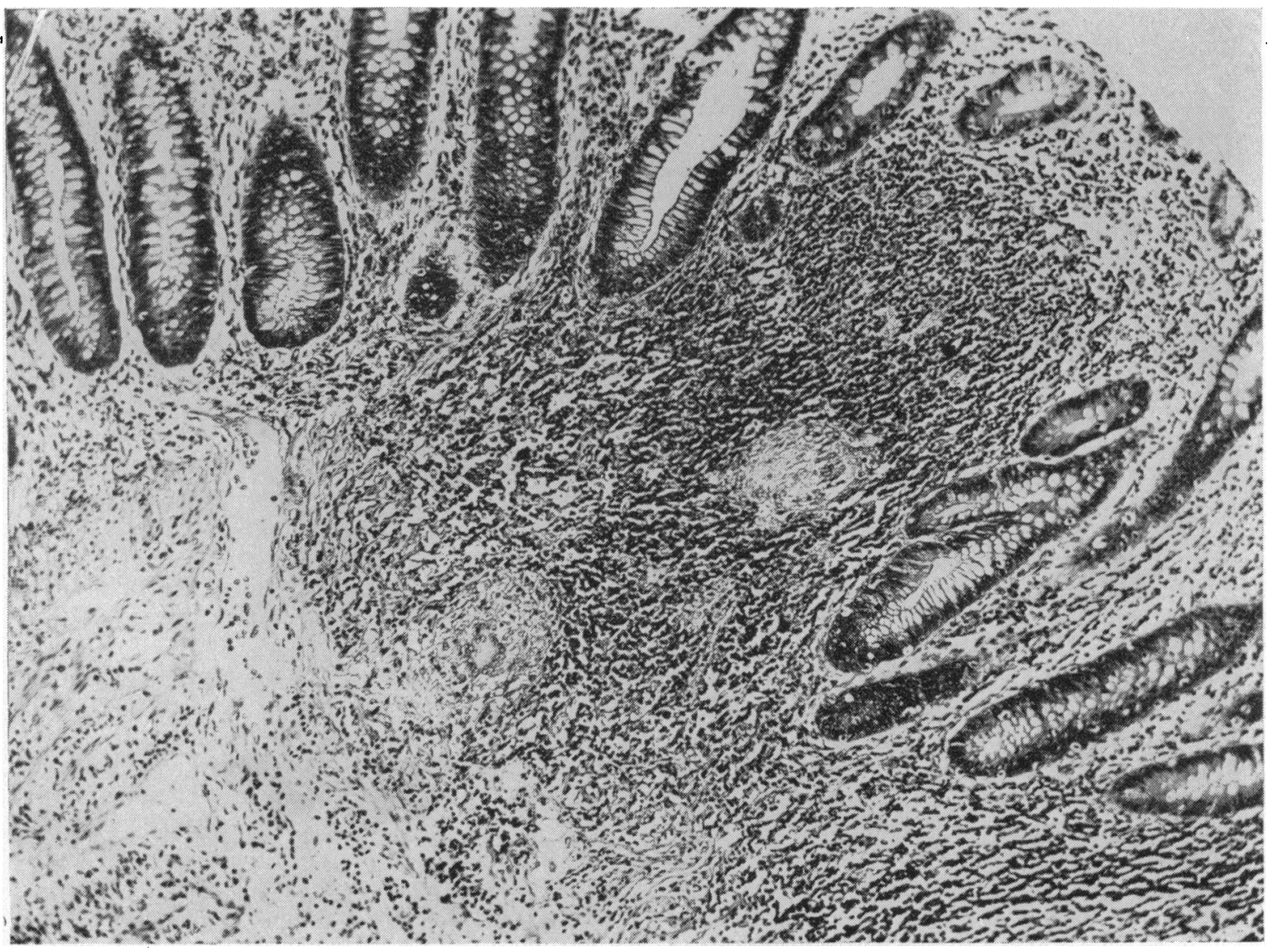

FIG. 1. Crohn's disease. Rectal biopsy showing tubercles and giant cells. $x 120$.

regional ileitis or primary Crohn's disease of the large intestine (Fig. 1).

Painful, swollen joints were found in seven of the 45 patients with primary Crohn's disease of the large intestine, in seven of the 86 patients with regional ileitis, and in 19 of the 200 patients with ulcerative colitis. Ankylosing spondylitis was found in two patients with regional ileitis and in two patients with ulcerative colitis. Erythema nodosum was seen in two patients with primary Crohn's disease of the large intestine, in five patients with regional ileitis, and in seven patients with ulcerative colitis.

Normal haemoglobin levels, above $11.5 \mathrm{~g}$. per $100 \mathrm{ml}$., were found in $43.2 \%$ of the patients with primary Crohn's disease of the large intestine, in $43.2 \%$ of the patients with regional ileitis, but in only $26 \%$ of the patients with ulcerative colitis. Haemoglobin levels below $60 \%$ (Haldane) were found in $9.1 \%$ of the patients with primary Crohn's disease of the large intestine, in $9.5 \%$ of the patients with regional ileitis, and in $21.6 \%$ of the patients with ulcerative colitis. The erythrocyte sedimentation rate was found to be a useful indicator of the activity of all three diseases. We were unable to demonstrate any special association between the $A B O$ and $R h$ anti-D blood groups and these three types of disease.

DISTRIBUTION OF LESIONS The distribution of the lesions in the small and large intestine in the patients with regional ileitis, ulcerative colitis, and primary Crohn's disease of the large intestine when surgical resections were first performed are shown in Table II.

Skip lesions were found in $43.3 \%$ of the patients with regional ileitis involving the large intestine (Fig. 2), in $20 \%$ of the patients with primary Crohn's disease of the large intestine (Fig. 3), and in only $1 \%$ of the patients with ulcerative colitis.

Involvement of the large intestine, found in 49 of the 86 patients with regional ileitis, was of two types. In the first type the lesions in the large intestine were in continuity with those in the terminal ileum and they appeared to be spreading along the large 


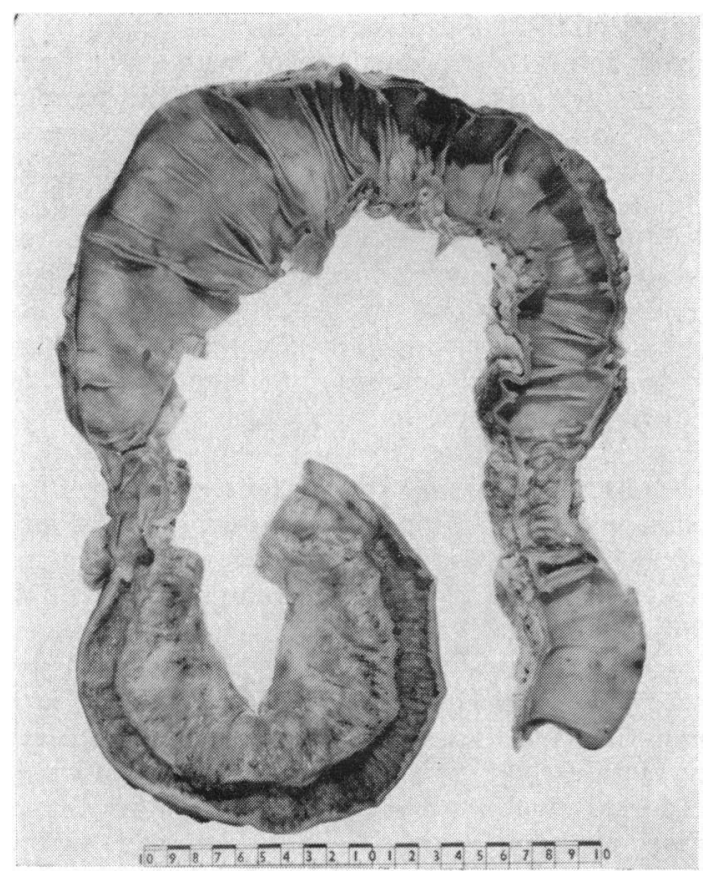

FIG. 2. Regional ileitis with skip lesion in descending colon.

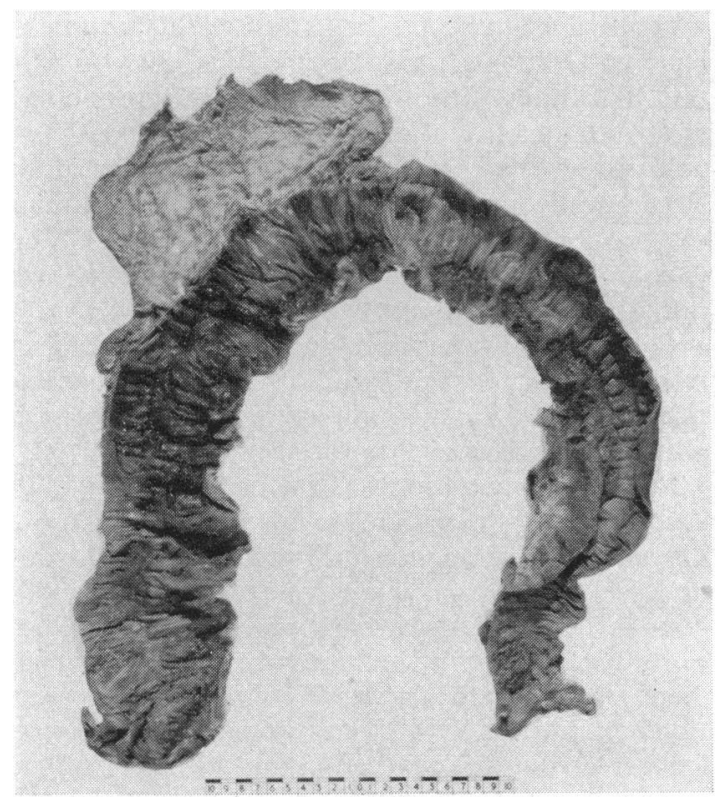

FIG. 3. Primary Crohn's disease of the large intestine with small intervening areas of normal mucosa. 


\section{TABLE II}

DISTRIBUTION OF LESIONS IN PRIMARY CROHN'S DISEASE OF LARGE INTESTINE, IN REGIONAL ILEITIS, AND IN ULCERATIVE COLITIS

\begin{tabular}{|c|c|c|c|}
\hline \multirow{2}{*}{$\begin{array}{l}\text { Distribution } \\
\text { Rectum to and including }\end{array}$} & \multicolumn{2}{|c|}{ No of Patients } & \multirow[t]{2}{*}{$\begin{array}{l}\text { No. with } \\
\text { Skip Lesio }\end{array}$} \\
\hline & & & \\
\hline Sigmoid colon & 5 & & $\mathbf{0}$ \\
\hline Descending colon & 4 & & 1 \\
\hline Transverse colon & 6 & & 1 \\
\hline Ascending colon & 1 & & $\mathbf{0}$ \\
\hline Caecum & 13 & 29 & 2 \\
\hline \multicolumn{4}{|l|}{ Caecum to and including } \\
\hline Ascending colon & 2 & & $\mathbf{0}$ \\
\hline Transverse colon & 1 & & 1 \\
\hline Descending colon & 3 & & 1 \\
\hline Sigmoid colon & 1 & 7 & $\mathbf{0}$ \\
\hline Ascending and transverse colon & & 1 & 1 \\
\hline Transverse to sigmoid colon & & 1 & $\mathbf{0}$ \\
\hline Caecum, sigmoid, and rectum & & 2 & 2 \\
\hline Transverse colon & & 3 & 0 \\
\hline \multirow[t]{2}{*}{ Sigmoid colon } & & 2 & $\mathbf{0}$ \\
\hline & Total & 45 & 9 \\
\hline \multicolumn{4}{|l|}{ Ileum to and including } \\
\hline Caecum & 11 & & 0 \\
\hline Ascending colon & 5 & & $\mathbf{0}$ \\
\hline Transverse colon & 5 & & 2 \\
\hline Descending colon & 3 & & $\mathbf{0}$ \\
\hline Sigmoid colon & 3 & & 3 \\
\hline Rectum & 7 & 34 & 1 \\
\hline Ileum with skip to sigmoid and rectum & & 13 & 13 \\
\hline \multicolumn{4}{|l|}{ Ileum and caecum, with skip to } \\
\hline stgmola and rectum & Total & $\begin{array}{r}2 \\
49\end{array}$ & 21 \\
\hline \multicolumn{4}{|l|}{ Rectum to and including } \\
\hline Sigmoid colon & 4 & & $\mathbf{0}$ \\
\hline Descending colon & 10 & & $\mathbf{0}$ \\
\hline Transverse colon & 11 & & $\mathbf{0}$ \\
\hline Ascending colon & 17 & & $\mathbf{0}$ \\
\hline Caecum & 115 & & 2 \\
\hline Terminal ileum & 41 & 198 & $\mathbf{0}$ \\
\hline \multirow{3}{*}{$\begin{array}{l}\text { Caecum to descending colon } \\
\text { Transverse colon }\end{array}$} & & 1 & $\mathbf{0}$ \\
\hline & & 1 & $\mathbf{0}$ \\
\hline & Total & 200 & 2 \\
\hline
\end{tabular}

intestine in a caudal direction (Fig. 4). In the second type lesions were found in the sigmoid colon and rectum which appeared to have been spread by a surface contact between the terminal ileum and the rectosigmoid. In several of these cases the surgeons found the terminal ileum stuck to the sigmoid colon by fibrous adhesions.

The incidence of segmental colitis varied with the different types of disease. It was uncommon in ulcerative colitis, but occurred in nearly one-third of the patients with primary Crohn's disease of the large intestine and in more than half the patients with regional ileitis involving the large intestine.

TREATMENT Ten patients with primary Crohn's disease of the large intestine were treated by total proctocolectomy, nine by subtotal proctocolectomy, nine by total colectomy, and 17 by subtotal colectomy. The disease was incompletely removed in $\mathbf{1 0}$ cases.

Twelve patients with regional ileitis were treated by resection of the diseased terminal ileum, 65 by removal of the terminal ileum with right hemicolectomy, and eight by removal of the terminal ileum with total colectomy. One patient was treated by the removal of a skip lesion in the sigmoid colon, the affected terminal ileum being left behind.

Most of the patients with ulcerative colitis were treated by total colectomy and ileo-rectal anastomosis, as described by Aylett (1960). Subtotal colectomy was performed in 11 cases, and palliative abdominoperineal excision of the rectum for advanced carcinoma in three cases.

MACROSCOPIC APPEARANCES There were no differences in the macroscopic or microscopic appearances of the large intestinal lesions in patients with regional ileitis and those of primary Crohn's disease of the large intestine.

Certain gross features helped to distinguish specimens of primary Crohn's disease of the large intestine from specimens of ulcerative colitis. A segmental distribution and the presence of skip lesions occurred much more frequently in Crohn's disease than in ulcerative colitis. The widespread, ragged, superficial ulceration seen in acute ulcerative colitis (Fig. 5) was not seen in the specimens of Crohn's disease, in which the ulcers were usually smaller, more elongated, and had a somewhat fissured appearance. The ulcers of Crohn's disease extended in a serpiginous fashion along the lumen of the bowel (Fig. 6), and occasionally branched or crossed each other to give a reticular pattern (Fig. 7). The mucosa between these ulcers was oedematous, the combination of fissures with a swollen mucosa producing a typical 'cobblestone' appearance.

Mucosal tags projecting into the lumen of the large intestine were a characteristic feature of many of the specimens of ulcerative colitis (Fig. 8). They were not found in the specimens from patients with primary Crohn's disease of the large intestine.

Dilatation of the colon was found in 24 specimens from patients with acute ulcerative colitis. No dilatation was found in any of the specimens from patients with Crohn's disease of the large intestine.

Serosal inflammation was a constant finding in the specimens from patients with primary Crohn's disease of the large intestine, and tiny greyish-white nodules, the size of a pin head, were seen on the serosal surface of six of these specimens. These serosal nodules were not found on the specimens from patients with ulcerative colitis. During operations on patients with ulcerative colitis the surgeons frequently noticed congestion and apparent inflammation of the serosal surface of the colon, but by the time most specimens reached the laboratory these features were no longer obvious. Specimens from 


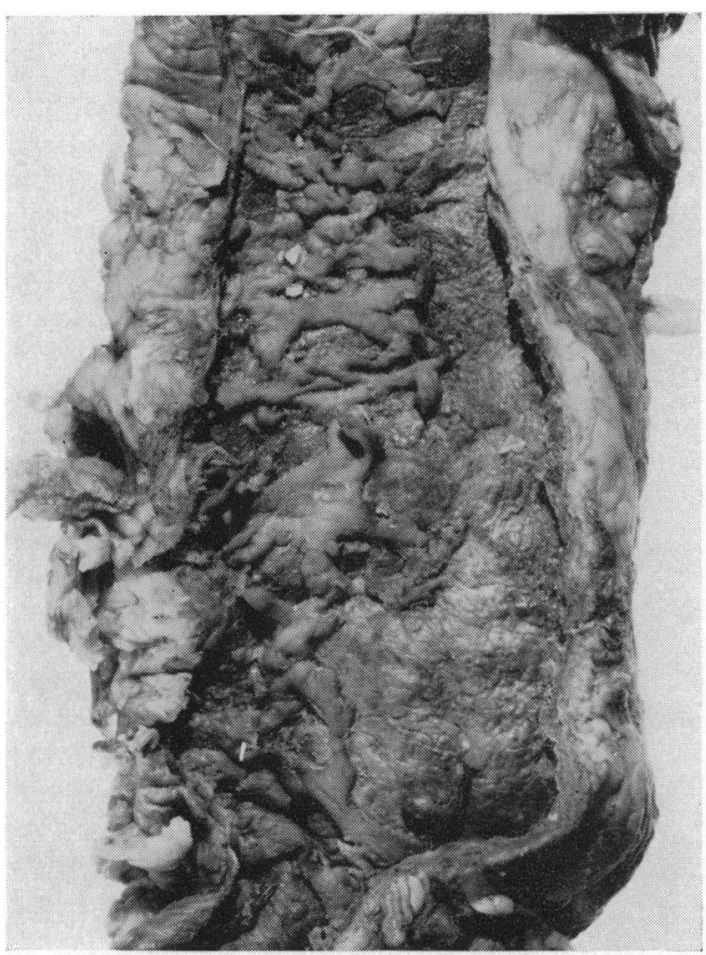

FIG. 5. Ulcerative colitis showing widespread ragged superficial ulceration.

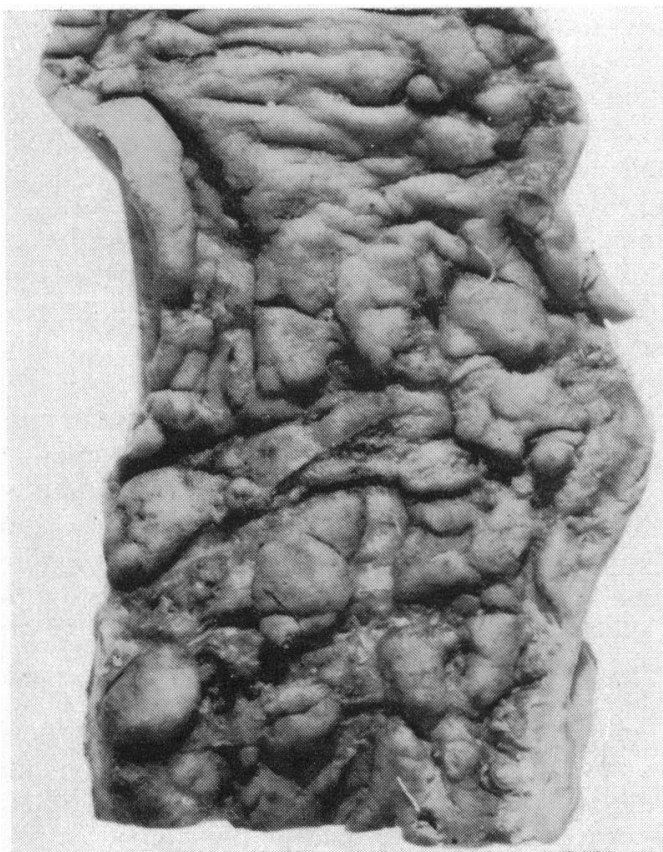

FIG. 6. Primary Crohn's disease of the large intestine. Close-up view of ulcers in the descending colon.

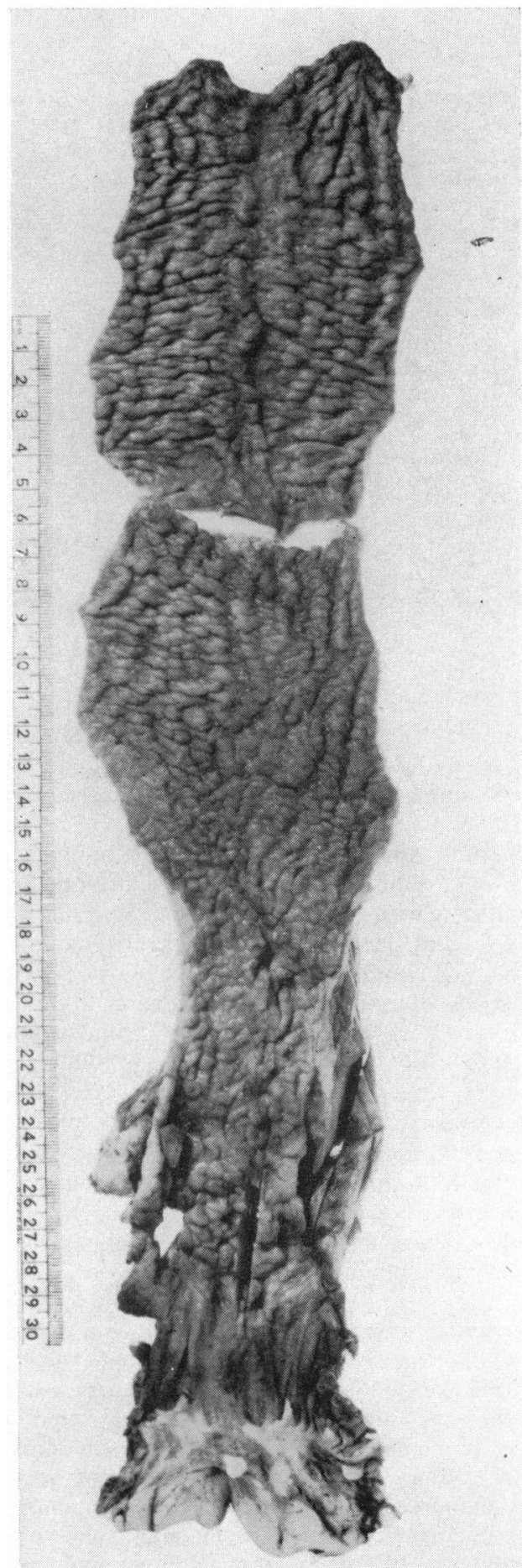

FIG. 7. Primary Crohn's disease of the sigmoid colon and rectum showing the characteristic 'cobblestone' appearance of the intestinal mucosa. 
FIG. 8. Ulcerative colitis with mucosal tags in the transverse colon.

patients with acute ulcerative colitis, however, invariably showed an acute inflammatory reaction of the serosal surface, and perforations were occasionally seen.

Internal fistulae were found in two patients with primary Crohn's disease of the large intestine and in 16 patients with regional ileitis. No internal fistula was found in the patients with ulcerative colitis.

Enlarged lymph nodes were found in $51.1 \%$ of the specimens of primary Crohn's disease of the large intestine, $68.9 \%$ of the specimens of ulcerative colitis, and $82.7 \%$ of the specimens of regional ileitis. The largest nodes were found in specimens from patients with ulcerative colitis and they frequently misled the surgeons into suspecting the presence of an associated carcinoma. Carcinomas were not found in any of these cases, however, and the large lymph nodes simply contained widely dilated sinusoids packed with chronic inflammatory cells.

MICROSCOPIC APPEARANCES Sections from the specimens of primary Crohn's disease of the large intestine showed a chronic inflammatory reaction affecting the submucosa, muscle coats, and subserosa. Some damage to the muscle coats was invariably found, and fibrous tissue was seen throughout the submucosa, and often in the muscle coats and subserosa as well. The muscle coats were usually considerably thickened, and the myenteric plexus and ganglion cells were prominent. Focal collections of lymphocytes were seen in the submucosa, muscle coats, and subserosa. Fissures extending into and often penetrating the muscle coats were frequently found, and were the basis for the formation of internal fistulae.

Foreign body type giant cells were seen in areas of ulceration and around abscesses in the wall of the large intestine. Non-caseating nodules of epithelioid histiocytes containing small multinucleated giant cells were found typically only in areas free from mucosal ulceration. These nodules were seen in the submucosa, muscle coats, subserosa, and regional lymph nodes. They were rarely found in enlarged lymph nodes. Schaumann bodies were seen in nodules of epithelioid cells in the large intestine of one patient with primary Crohn's disease of the large intestine and in the pericolic lymph nodes of two other patients with this disorder.

Brunner-type glands were found in specimens of terminal ileum from 29 patients with regional ileitis (Fig. 9). They were found only in areas of mucosal regeneration, and were often only partly stained by the indulin-mucicarmine technique of Kawel and Tesluk (1955). Despite an extensive search we were unable to find these glands in the large intestine in any of the cases studied, or in the terminal ileum affected by ulcerative colitis.

Severe ulceration with damage to the muscle coats and an acute inflammatory reaction in the muscle coats and subserosa were seen in specimens from patients with severe acute ulcerative colitis.

In chronic ulcerative colitis the inflammatory reaction was limited to the mucosa and submucosa, and only tiny perineural and perivascular collections 


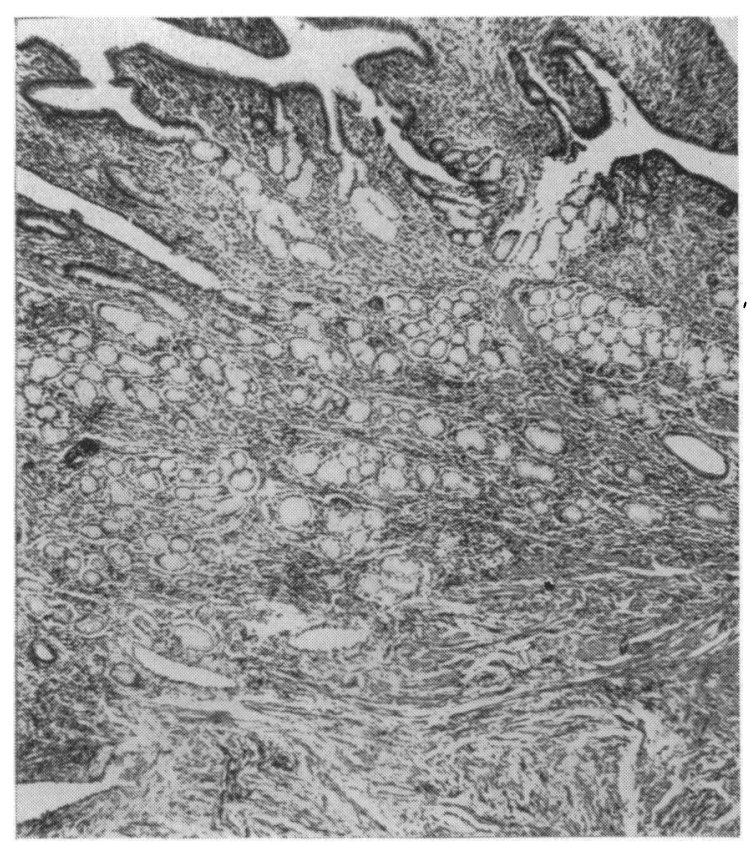

FIG. 9. Brunner-type glands in the submucosa of the terminal ileum, from a patient with regional ileitis. $\times 60$.

of lymphocytes were seen in the muscle coats and subserosa. Mucosal tags and granulomatous polypi were found in 97 of the 157 specimens from patients with chronic ulcerative colitis. Crypt abscesses, mucosal ulceration, and some epithelial regeneration were present in all the specimens from patients with chronic active disease. Damage to the muscle coats was not seen and fibrosis, which was minimal, was limited to the superficial submucosa. Thickening of the bowel wall and narrowing of the intestinal lumen was invariably associated with a thickening of the muscle coats, and the myenteric plexus and ganglion cells were unusually prominent in these cases.

CARCINOMA Carcinomas were found in the specimens from 17 patients with ulcerative colitis. No carcinoma was found in the specimens from patients with primary Crohn's disease of the large intestine. Rectal carcinomas were found in specimens from two patients with regional ileitis. In the first case the rectal carcinoma was found five years after the surgical resection of the diseased terminal ileum and at the second operation there was no evidence of recurrent disease in the small intestine or of regional ileitis involving the large intestine. In the second case the patient presented with a rectal carcinoma and regional ileitis and both were treated by surgical resection. There was no evidence of regional ileitis
TABLE III

RELATIONSHIP BETWEEN LENGTH OF HISTORY AND DEVELOPMENT OF CARCINOMA IN DISEASED INTESTINE

\begin{tabular}{|c|c|c|c|c|}
\hline \multirow{3}{*}{$\begin{array}{l}\text { Length of } \\
\text { History } \\
\text { (years) }\end{array}$} & \multicolumn{4}{|c|}{ Number of Cases } \\
\hline & \multirow{2}{*}{$\begin{array}{l}\text { Regional } \\
\text { Ileitis }^{1}\end{array}$} & \multirow{2}{*}{$\begin{array}{l}\text { Primary Crohn's } \\
\text { Disease of } \\
\text { Large Intestine }\end{array}$} & \multicolumn{2}{|c|}{ Ulcerative Colitis } \\
\hline & & & Total & $\begin{array}{l}\text { With } \\
\text { Carcinoma }\end{array}$ \\
\hline $0-5$ & 42 & 28 & 49 & 2 \\
\hline $6-10$ & 21 & 10 & 70 & 3 \\
\hline $11-15$ & 11 & 4 & 32 & 1 \\
\hline $16-20$ & 7 & 1 & 22 & 7 \\
\hline $21-25$ & 3 & 1 & 17 & 3 \\
\hline $26-30$ & 0 & 0 & 5 & 1 \\
\hline 30 plus & 2 & 1 & 5 & 0 \\
\hline Total & 86 & 45 & 200 & 17 \\
\hline
\end{tabular}

involving the rectum, and the remainder of the large intestine appeared normal.

The failure to demonstrate carcinoma in areas of regional ileitis or primary Crohn's disease of the large intestine may be related to their shorter length of history (Table III). Whilst the total incidence of carcinoma in patients with ulcerative colitis treated by all forms of surgery was $8.6 \%$, the incidence in those with ulcerative colitis of more than 10 years' duration was $14.8 \%$, and of more than 15 years' duration was $22.4 \%$.

INCIDENCE OF PRIMARY CROHN'S DISEASE OF THE LARGE INTESTINE From January 1949 until the end of January 1960 surgical resections of a part or all of the large intestine were performed at the Gordon Hospital, London, on 200 patients with ulcerative colitis. In the same period and at the same hospital surgical resections of part or all of the large intestine were performed on 13 patients with primary Crohn's disease of the large intestine. The surgical incidence of primary Crohn's disease of the large intestine relative to ulcerative colitis was therefore roughly one in every 15 cases.

RECURRENCE AFTER SURGICAL RESECTION No recurrence was found in the small intestine after total colectomy for ulcerative colitis. Recurrence in the previously unaffected right side of the colon was found in two patients with ulcerative colitis treated by left hemicolectomy.

So far no recurrence has been found in the small intestine following the surgical treatment of primary Crohn's disease of the large intestine. Recurrence in previously unaffected segments of large intestine within a year of operation occurred in four patients treated by subtotal colectomy. In two patients the disease recurred in segments immediately proximal 
to the primary lesion, and in two patients in segments immediately distal to the primary lesion.

Thirty-two of the 86 patients with regional ileitis developed a recurrence in unaffected segments of the small or large intestine after surgical resection. A second resection was performed on 28 of these patients. In the four remaining patients recurrence was indicated by a recurrence of symptoms and radiological evidence of disease. Recurrent disease affected the ileum and jejunum in one case, the ileum in 23 cases, and the ileum and large intestine in eight cases. In 13 cases disease recurred within two years, in 22 cases within five years, in 31 cases within 10 years, and in all the cases within 12 years.

\section{DISCUSSION}

Because these studies are based solely on surgical material they necessarily give a biased picture of the diseases investigated since they ignore all the patients with the milder forms of these diseases who did not require any surgical treatment. This is particularly important when complications such as fistulae or carcinoma are considered, conditions which necessarily bring the patient to the surgical clinic. However, the careful examination of resected specimens provides the most reliable method so far available of distinguishing cases of primary Crohn's disease of the large intestine from that of ulcerative colitis.

It may be argued that our histological criteria for the diagnosis of primary Crohn's disease of the large intestine are too strict, and that we have excluded cases which others might regard as examples of this condition. In our present state of knowledge we believe this to be a wise procedure. Nothing is gained and much may be lost by trying to classify doubtful specimens as atypical cases of ulcerative colitis or atypical cases of Crohn's disease of the large intestine.

Despite these and other limitations the results show that it is worth distinguishing between ulcerative colitis, primary Crohn's disease of the large intestine, and regional ileitis with large intestinal involvement.

CLINICAL FEATURES In this study regional ileitis was found to be commoner in men than in women, and primary Crohn's disease of the large intestine to be commoner in women than in men. Primary Crohn's disease of the large intestine occurred in an older age group than regional ileitis or ulcerative colitis, and approximately one-quarter of the cases occurred in women over 60 years of age. In the series of 25 cases reported by Lockhart-Mummery and Morson their seven cases of regional ileitis with large intestinal involvement all occurred in men, whose ages ranged from 17 to 49 years with a mean of 27 years. Of their 18 cases of primary Crohn's disease of the large intestine, 10 occurred in men and eight in women, their ages ranging from 34 to 72 years with a mean of 54 years.

Patients with primary Crohn's disease of the large intestine frequently present with segmental colitis. When only a short segment of the large intestine is affected the lesion can mimic carcinoma (Moynihan, 1907; Robson, 1908), and the frequent occurrence of primary Crohn's disease of the large intestine in patients over 50 years of age adds to the difficulty in separating the two diseases clinically. Similarly when Crohn's disease is limited to the sigmoid colon and the patient is over 50 years of age a diagnosis of diverticulitis may be made. This happened twice in our series and subtotal colectomies were performed. Examination of the operation specimens, however, showed Crohn's disease and no diverticulum could be found.

A gradual onset and a continuous course were common findings in patients with primary Crohn's disease of the large intestine and this probably accounts for their short clinical histories before surgical resections were undertaken. It is also possible that the Crohn's disease might have been latent in the colon for several years before its presence became clinically manifest. Periods of complete freedom from disease lasting a month or more, found in more than half the patients with ulcerative colitis, were uncommon in patients with primary Crohn's disease of the large intestine. Diarrhoea and melaena, characteristic features of ulcerative colitis, occurred less frequently and were less severe in most of the patients with primary Crohn's disease of the large intestine. These clinical observations tied up with the lesser degree of mucosal ulceration and the more frequent finding of normal haemoglobin levels in patients with Crohn's disease of the large intestine than in patients with ulcerative colitis.

FISTULAE Perianal and rectovaginal fistulae were found more frequently in patients with primary Crohn's disease of the large intestine than in patients with regional ileitis or ulcerative colitis. Similar findings have been reported by Lockhart-Mummery and Morson. In their series anal fistulae were found in $42.8 \%$ of the cases of regional ileitis with large intestinal involvement, and in $77.8 \%$ of the cases of primary Crohn's disease of the large intestine. The finding of multiple fistulae, indolent anal lesions, and recurrence after surgical treatment suggests a diagnosis of Crohn's disease rather than ulcerative colitis. All material removed at operations on anal fistulae should be sent to the laboratory for examination. The finding of non-caseating tubercles with Langhans 
type giant cells in this material may then draw attention to a previously unsuspected case of regional ileitis or primary Crohn's disease of the large intestine (Morson and Lockhart-Mummery, 1959).

RECTAL DISEASE Difficulty may be experienced in separating the sigmoidoscopic appearances of ulcerative colitis and Crohn's disease. The finding of granular areas with intervening areas of normal or slightly oedematous mucosa suggests the diagnosis of Crohn's disease (Lockhart-Mummery and Morson, 1960). Rectal biopsy may help to establish the diagnosis of Crohn's disease when non-caseating tubercles with Langhans type giant cells are found. The majority of biopsies, however, fail to show these tubercles, and no great importance should be attached to a negative finding.

PATHOLOGY Although the combination of Crohn's disease and ulcerative colitis occurring in the same patient has been frequently reported in the American literature (Crohn and Yarnis, 1958; Colcock and Vansant, 1960), we have not seen any example of this combination. The few supposed examples which we have seen proved to be cases of ileostomy dysfunction after total proctocolectomy for ulcerative colitis (see Counsell, 1956), or cases of Crohn's disease of the large intestine in which few sections had been taken for histology and the presence of non-caseating tubercles in the intestinal wall or regional lymph nodes had been missed.

Finding Brunner-type glands in a tuberculous ulcer of the large intestine was first reported by Nicholson in 1923, and in 1951 Liber reported finding them in the terminal ileum of four patients with regional ileitis. We did not find these glands in the large intestine in any of the cases studied, and found them only in the terminal ileum affected by regional ileitis. Their partial staining reaction with indulin and mucicarmine and their occurrence only in areas of epithelial regeneration suggests a form of metaplasia developing in the healing phase of regional ileitis. Kawel and Tesluk (1955), however, reported a high incidence of recurrent disease after the surgical treatment of regional ileitis when these glands were present in the terminal ileum. In our series the recurrence rate was the same whether these glands were present or not. Similar findings have been reported by Antonius, Gump, Lattes, and Lepore (1960).

It is often stated that the histological appearances of the non-caseating nodules of epithelioid histiocytes found in patients with Crohn's disease are similar to those found in sarcoidosis. But a critical comparison of the lesions found in lymph nodes from patients with these diseases reveals a number of distinguishing features. In sarcoidosis, the lymph nodes are usually considerably enlarged and many noncaseating nodules of epithelioid cells are found inside them. In Crohn's disease, the nodules are found most frequently in normal-sized nodes and only a few nodules can be seen. In sarcoid, the nodules show a monotonous uniformity of size, shape, and stage of development. In Crohn's disease, the nodules vary considerably in size, shape, and degree of maturity, and are usually smaller than those seen in sarcoid. In sarcoid the nodules are cellular and compact. In Crohn's disease the epithelioid cells are more loosely arranged, and the cell margins are frequently separated by oedema. The multinucleated giant cells of sarcoidosis often contain more than 30 nuclei, whilst those in Crohn's disease seldom contain more than 16 and appear to be formed by the fusion of endothelial cells lining affected lymphatic capillaries.

It is not generally appreciated that sarcoid-like lesions can be found in the wall of the intestine close to carcinomas and villous papillomas (Dawson, 1961), and that similar lesions may be found in the regional lymph nodes draining carcinomas from many different parts of the body (Gresham and Ackerley, 1958). It is possible that some of the socalled cases of carcinoma with regional ileitis reported in the literature are of this type.

DEVELOPMENT OF CARCINOMA So far no definite tendency to malignant change has been established in patients suffering from Crohn's disease (Nevin, 1961). Carcinoma of the large intestine is, however, a well-recognized complication of ulcerative colitis, and its incidence appears to be related to the duration of the colitis rather than to the age at onset of the disease (Counsell and Dukes, 1952; Dawson and Pryse-Davies, 1959). The fact that no carcinoma occurred in areas of regional ileitis or primary Crohn's disease of the large intestine in the present series may be related to the finding that these patients came to surgery earlier than the patients with ulcerative colitis. It may also be related to the degree of mucosal ulceration, epithelial proliferation, and polyp formation being less marked in regional ileitis and primary Crohn's disease of the large intestine than in ulcerative colitis.

PROGNOSIS It is not the purpose of this communication to evaluate the different methods of treatment employed but we have noticed that several patients with primary Crohn's disease of the large intestine who had failed to obtain any adequate measure of relief by medical treatment were quickly restored to normal health by surgical treatment and have continued to enjoy a prolonged period of freedom from disease. Unnecessary delay in the surgical treatment of segmental colitis can result in rectal involvement, 
the formation of perianal and rectovaginal fistulae, and the subsequent failure of ileorectal anastomosis. The high incidence of recurrent disease after surgical treatment found in patients with regional ileitis has not been found in patients with Crohn's disease arising primarily in the large intestine. It is too soon to judge whether primary Crohn's disease of the large intestine has a better prognosis than regional ileitis but the results of surgical resection are so far most encouraging.

\section{SUMMARY}

This study is based on $\mathbf{4 5}$ patients suffering from a non-specific chronic inflammatory disorder confined entirely to the large intestine. The pre-operative clinical diagnoses were idiopathic ulcerative colitis, diverticulitis, or carcinoma. Examination of the specimens removed at operation showed many of the characteristic pathological features of regional ileitis. For the sake of convenience these cases have been called primary Crohn's disease of the large intestine. The clinical and pathological features of these 45 cases are compared with 86 cases of regional ileitis and 200 cases of ulcerative colitis.

Compared with regional ileitis the disease occurred in an older age group, had a different sex distribution and a higher incidence of perianal and rectovaginal fistulae. A high incidence of recurrent disease following surgical treatment, found in the patients with regional ileitis, was not found in the patients with primary Crohn's disease of the large intestine.

The incidence of the disease relative to ulcerative colitis was approximately $6 \%$. The disease had the same sex distribution as ulcerative colitis but occurred in an older age group. The disease usually had a gradual onset and continuous course, and periods of freedom lasting a month or more were uncommon. The patients came to surgery much earlier than patients with ulcerative colitis. Diarrhoea, melaena, and mucosal ulceration were less marked, and a normal pre-operative haemoglobin level was found in over $40 \%$ of the patients. Perianal and rectovaginal fistulae, found in two-thirds of the patients, were frequently multiple, indolent, and tended to recur after surgical treatment. The incidence of skip lesions and segmental colitis was much higher than that found in ulcerative colitis. The mucosal ulcers were usually elongated and fissured, and the intervening oedematous mucosa had a cobblestone appearance. The widespread ragged superficial ulceration, pseudo-polypi, dilated bowel and perforations, found in some cases of ulcerative colitis, were not seen in primary Crohn's disease of the large intestine.

Carcinomas of the large intestine were found in specimens from 17 patients with ulcerative colitis. No carcinoma was found in regional ileitis or primary Crohn's disease of the large intestine. This may be related to a shorter clinical history and a lesser degree of mucosal ulceration, epithelial proliferation, and polyp formation.

Gratitude is expressed to Professor R. J. V. Pulvertaft for the opportunity to undertake this work, for the provision of research facilities, and for much encouragement in the preparation of this paper. We are grateful to Dr. Cuthbert Dukes for suggesting the method of investigation used in this study. Appreciation is expressed to Mr. Stanley Aylett, Mr. Bryan Brooke, Dr. I. M. P. Dawson, Dr. C. E. Dukes, Mr. H. E. Lockhart-Mummery, and Dr. B. C. Morson for much helpful advice and criticism. We wish to thank Dr. O. Bjarnason, Mr. Bryan Brooke, Dr. I. M. P. Dawson, Professor C. V. Harrison, Dr. D. H. Mackenzie, Dr. A. D. Morgan, Dr. B. C. Morson, and Mr. Gordon Ungley for the opportunity to study specimens of primary Crohn's disease of the large intestine. We are grateful to Dr. Peter Hansell and Mr. E. V. Pittock for the photography, and to Miss Gloria Fisher for technical assistance. The work was made possible by block grants from the British Empire Cancer Campaign to the Westminster Medical School and the Research Department of St. Mark's Hospital, London.

\section{REFERENCES}

Antonius, J. I., Gump, F. E., Lattes, R., and Lepore, M. (1960). A study of certain microscopic features in regional enteritis, and their possible prognostic significance. Gastroenterology, 38 , 889-905.

Aylett, S. O. (1960). Diffuse ulcerative colitis and its treatment by ileo-rectal anastomosis. Ann. roy. Coll. Surg. Engl., 27, 260-284.

Braun, H. (1909). Über entzündliche Geschwülste am Darm. Dtsch. Z. Chir., 100, 1-12.

Brooke, B. N. (1959). Granulomatous diseases of the intestine. Lancet, 2, 745-749.

Brown, P. W., Bargen, J. A., and Weber, H. M. (1934). Chronic inflammatory lesions of the small intestine (regional enteritis). Amer. J. dig. Dis., 1, 426-431.

Castleman, B. (1944). Case records of the Massachusetts General Hospital. Case 30172. New Engl. J. Med., 230, 526-529.

Colcock, B. P., and Vansant, J. H. (1960). Surgical treatment of regional enteritis. New Engl. J. Med., 262, 435-439.

Colp, R. (1934). A case of nonspecific granuloma of the terminal ileum and the cecum. Surg. Clin. N. Amer., 14, 443-449.

Counsell, B. (1956). Lesions of the ileum associated with ulcerative colitis. Brit. J. Surg., 44, 276-290.

- , and Dukes, C. E. (1952). The association of chronic ulcerative colitis and carcinoma of the rectum and colon. Ibid., 39, 485-495.

Crohn, B. B., Ginzburg, L., and Oppenheimer, G. D. (1932). Regional ileitis. A pathologic and clinical entity. J. Amer. med. Ass., 99, 1323-1329.

colitis. Ibid., 106, 1-7.

- and Yarnis, H. (1958). Regional Ileitis, 2nd ed. Grune and Stratton, New York and London.

Dalziel, T. K. (1913). Chronic interstitial enteritis. Brit. med. J., 2, 1068-1070.

Dawson, I. M. P. (1961). Villous papilloma of the rectum with giant cell systems. Proc. roy. Soc. Med., 54, 723.

- and Pryse-Davies, J. (1959). The development of carcinoma of the large intestine in ulcerative colitis. Brit. J. Surg., 47, 113-128.

Donchess, J. C., and Warren, S. (1934). Chronic cicatrizing enteritis with involvement of the cecum and the colon. Arch. Path. (Chicago), 18, 22-29. 
Dukes, C. E. (1954). The surgical pathology of ulcerative colitis. Ann. roy. Coll. Surg. Engl., 14, 389-400.

- (1959). Personal communication.

- , and Lockhart-Mummery, H. E. (1957). Practical points in the pathology and surgical treatment of ulcerative colitis. Brit. $J$. Surg., 45, 25-36.

Goldgraber, M. B., Kirsner, J. B., and Palmer, W. L. (1959). The histopathology of chronic ulcerative colitis and its pathogenic implications. Proceedings of the World Congress of Gastroenterology, Washington, D.C., 1958. Vol. 2, pp. 935-943. Williams and Wilkins, Baltimore.

Goligher, J. C. (1961). Surgical treatment of ulcerative colitis. Brit. med. J., 1, 151-154.

Gresham, G. A., and Ackerley, A. G. (1958). Giant cell granulomata in regional lymph nodes of carcinoma.J. clin. Path., 11, 244-250.

Hadfield, G. (1939). The primary histological lesion of regional ileitis. Lancet, 2, 773-775.

Harris, F. I., Bell, G. H., and Brunn, H. (1933). Chronic cicatrizing enteritis; regional ileitis (Crohn). A new surgical entity. Surg. Gynec. Obstet., 57, 637-645.

James, T. G. I. (1938). Chronic regional colitis. Brit. J. Surg., 25, 511-516.

Kawel, C. A., Jr., and Tesluk, H. (1955). Brunner-type glands in regional enteritis. Gastroenterology, 28, 810-820.

Läwen, A. (1914). Uber Appendicitis fibroplastica. Dtsch. Z. Chir., 129, 221-241.

Liber, A. F. (1951). Aberrant pyloric glands in regional enteritis. A.M.A. Arch Path., 51, 205-212.

Lockhart-Mummery, H. E., and Morson, B. C. (1960). Crohn's disease (regional enteritis) of the large intestine and its distinction from ulcerative colitis. Gut, 1, 87-105.
Lumb, G. (1951). Cicatrizing enterocolitis. Brit. J. Surg., 39, 233-243.

- , and Protheroe, R. H. B. (1958). Ulcerative colitis. A pathologic study of 152 surgical specimens. Gastroenterology, 34, 381-407.

Morson, B. C., and Lockhart-Mummery, H. E. (1959). Anal lesions in Crohn's disease. Lancet, 2, 1122-1123.

Moschcowitz, E., and Wilensky, A. O. (1923). Non-specific granulomata of the intestine. Amer. J. med. Sci., 166, 48-66.

Moynihan, B. G. A. (1907). The mimicry of malignant disease in the large intestine. Edinb. med. J., n.s. 21, 228-236.

Neuman, H. W., Bargen, J. A., and Judd, E. S. (1954). A clinical study of two hundred and one cases of regional (segmental) colitis. Surg. Gynec. Obstet., 99, 563-571.

Nevin, R. W. (1961). A review of granulomata of the large intestine. Proc. roy. Soc. Med., 54, 137-142.

Nicholson, G. W. (1923). Heteromorphoses (metaplasia) of the alimentary tract. J. Path. Bact., 26, 399-417.

Rappaport, H., Burgoyne, F. H., and Smetana, H. F. (1951). The pathology of regional enteritis. Milit. Surg., 109, 463-502.

Robson, A. W. M. (1908). An address on some abdominal tumours simulating malignant disease, and their treatment. Brit. med. J., 1, 425-428.

Tietze, A. (1920). Über entzündliche Dickdarmgeschwülste. Ergebn. Chir. Orthop., 12, 211-273.

Warren, S., and Sommers, S. C. (1948). Cicatrizing enteritis (regional ileitis) as pathologic entity: analysis of 120 cases. Amer. J. Path., 24, 475-501.

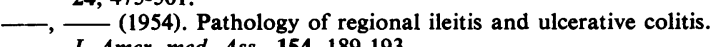
J. Amer. med. Ass., 154, 189-193.

Watkinson, G., Thompson, H., and Goligher, J. C. (1960). Rightsided or segmental ulcerative colitis. Brit. J. Surg., 47, 337-351.

Wells, C. (1952). Ulcerative colitis and Crohn's disease. Ann. roy. Coll. Surg. Engl., 11, 105-120. 